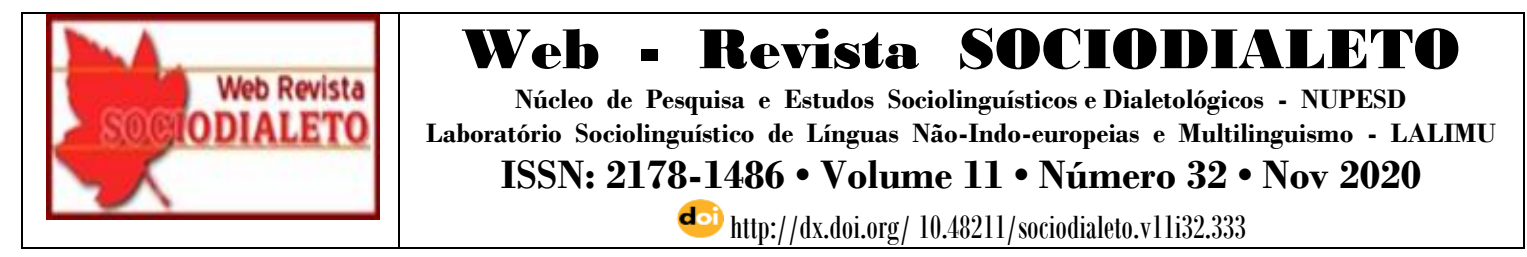

\title{
O CONTATO PORTUGUÊS-FRANCÊS E O BILINGUISMO SOCIETAL DOS CATRAIEIROS NA FRONTEIRA FRANCO- BRASILEIRA $^{1}$
}

\author{
Lizandra Valéria da Silva Fumelê (UEAP)² \\ valeriafumele123.ap@gmail.com \\ Kelly Cristina Nascimento Day (UEAP) ${ }^{3}$ \\ kelly.day@ueap.edu.br
}

\begin{abstract}
RESUMO: As regiões de fronteira entre nações constituem ambientes propícios para a emergência de situações de bilinguismo. Nesse contexto, o presente trabalho tem como objetivo apresentar o(s) processo(s) de formação bilíngue dos trabalhadores denominados catraieiros que operam a travessia de passageiros através de catraias na fronteira franco-brasileira, entre as cidades de Oiapoque e Saint-Georges. O suporte teórico-metodológico utilizado nesse estudo tem como base aportes da Sociolinguística discutidos por Labov (1966), estudos do Contato Linguístico a partir das contribuições de Weinrich (1953) e Romaine (1997), e as noções de bilinguismo a partir de uma perspectiva societal, conforme discussões apresentadas por Mackey (1972), Hamers \& Bland (2000), entre outros. Os procedimentos metodológicos empregados na pesquisa são de cunho etnográfico. A pesquisa de campo, de natureza qualitativa, teve como instrumentos de coleta de dados o questionário, a entrevista semiestruturada e as notas de campo. Os resultados obtidos evidenciam que os catraieiros constituem um grupo bilíngue/ plurilíngue, com baixo nível de escolaridade, mas que falam, em sua maioria, mais de duas línguas dentre aquelas em uso na fronteira franco-brasileira; que o processo de formação bilíngue está fundamentado na convivência com os franceses metropolitanos e guianenses que atravessam diariamente a fronteira e que o nível de conhecimento das línguas é muito variável dentro do grupo.
\end{abstract}

PALAVRAS- CHAVE: Bilinguismo societal; Formação bilíngue; Fronteira Franco -Brasileira.

RÉSUMÉ: Les régions frontalières entre les nations sont des environnements favorables à l'émergence de situations de bilinguisme. Dans ce contexte, le présent travail vise à présenter le (s) processus (s) de formation bilingue des travailleurs appelés catraieiros qui opèrent le franchissement des passagers par catraias à la frontière franco-brésilienne, entre les villes d'Oiapoque et Saint-Georges. Le soutien théorique et méthodologique utilisé dans cette étude est basé sur les contributions de la sociolinguistique discutées par Labov (1966), les études de Contact Linguistique par des contributions de Weinrich (1953) et de Romaine (1997), et les notions de bilinguisme dans une perspective sociétale, comme l'ont expliqué Mackey (1972), Hamers et Bland (2000), entre autres. Les procédures méthodologiques utilisées dans la recherche sont de nature ethnographique. La recherche de terrain, de nature qualitative, avait pour instruments de collecte de données le questionnaire, l'entretien semi-structuré et les notes de terrain. Les résultats obtenus

\footnotetext{
${ }^{1} \mathrm{O}$ presente artigo se insere no âmbito do projeto de pesquisa Estudos da paisagem Linguística da fronteira Amapá-Guiana Francesa: desenvolvido pelo grupo de pesquisa LINLIS da Universidade do Estado do Amapá.

2 Acadêmica do Curso de Letras-Francês da Universidade do Estado do Amapá (UEAP). Bolsista do Programa Institucional de Bolsas de Iniciação Científica - PIBIC/ CNPq. Contato: valeriafumele123.ap@gmail.com

${ }^{3}$ Professora Adjunta na Universidade do Estado do Amapá (UEAP). Orientadora no Programa Institucional de Bolsas de Iniciação Científica - PIBIC/ CNPq. Contato: kelly.day@ueap.edu.br
} 


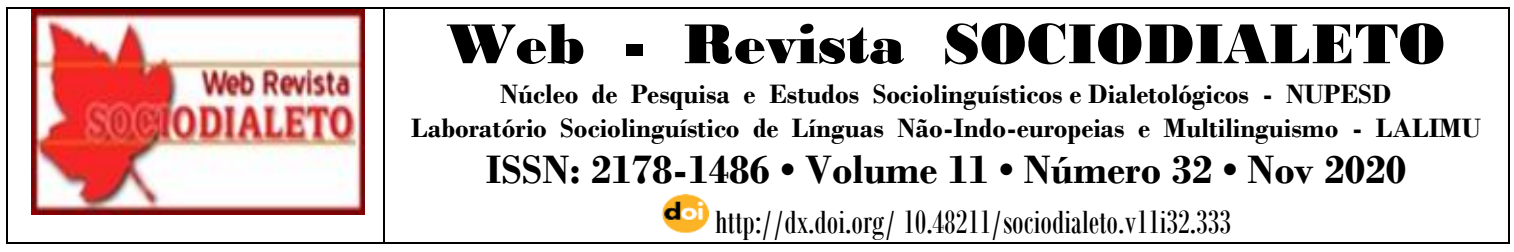

montrent que les catraieiros constituent un groupe bilingue / plurilingue, peu scolarisé, mais qui parlent majoritairement plus de deux langues parmi celles en usage à la frontière franco-brésilienne; que le processus de formation bilingue est basé sur la vie avec la métropole française et les Guyanais qui traversent la frontière quotidiennement et que le niveau de connaissance des langues varie largement au sein du groupe.

MOTS CLÉS: Bilinguisme Sociétal; Formation Bilingue; Frontière Franco-Brésilienne.

\section{Introdução}

As fronteiras brasileiras, de modo geral, são espaços limítrofes que registram o contato linguístico do português com o espanhol e nesse contexto diversos trabalhos têm mostrado a fecundidade das pesquisas em torno dos fenômenos do contato nessas áreas. A fronteira Brasil - Guiana Francesa, por sua vez, apresenta uma configuração única no contexto das fronteiras brasileiras demarcada pelo encontro do português com o francês e demais línguas de base francesa presentes na região.

Diferente das fronteiras que já reúnem trabalhos mais amplamente reconhecidos como Rivera e Santana do Livramento, Aceguá e Aceguá, Chui, Chuy, entre outros, a fronteira Oiapoque/Saint-Georges tem uma realidade linguística ainda pouco discutida e conhecida. Dentre os trabalhos já realizados no âmbito dos estudos do contato linguístico podemos citar o panorama sociolinguístico das línguas em presença realizado por Day (2005), as discussões feitas por Llorens (2006) acerca do ensino das línguas francesa e portuguesa na fronteira e o trabalho de Ribeiro (2016) que retrata os aspectos da influência fonológica no falar fronteiriço.

A fronteira franco-brasileira, delimitada pelo rio Oiapoque, até bem pouco tempo, só vivenciava a integração entre as comunidades francesa e brasileira a partir da utilização de catraias - meio de transporte utilizado na travessia entre as fronteiras. Esse transporte fluvial é conduzido pelos barqueiros conhecidos na região como catraieiros. A condição bilíngue desse grupo é, portanto, condição fundamental para o desenvolvimento e o sucesso da atividade. 


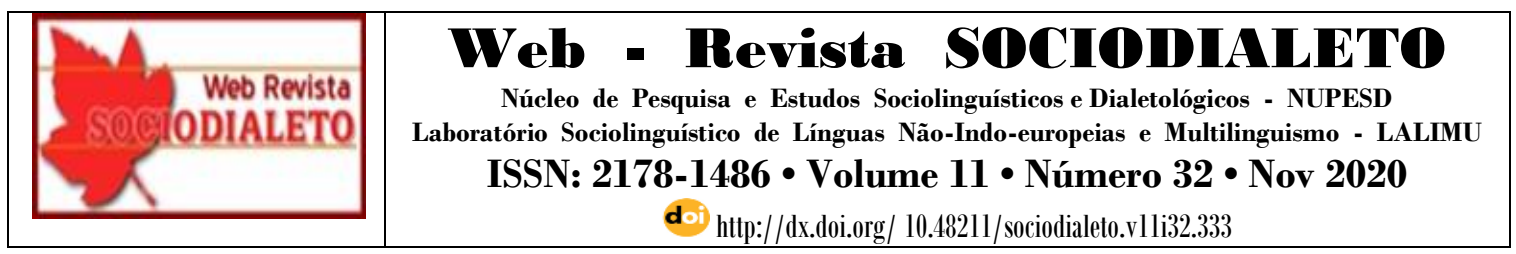

Nesse cenário, considerando que as fronteiras são zonas peculiares para o surgimento de sociedades bilíngues ou multilíngues, o presente trabalho tem como intuito determinar e analisar de que maneira tem ocorrido o processo de formação bilíngue dos trabalhadores catraieiros na fronteira franco-brasileira. Tendo como pano de fundo a dinâmica comunicativa entre brasileiros e estrangeiros e as estratégias utilizadas para que haja interação, buscou-se nesse trabalho compreender a constituição de um grupo social bilíngue no contexto de uma comunidade considerada majoritariamente monolíngue, ainda que haja um fluxo constante de pessoas entre as duas regiões.

Assim, o presente trabalho está composto por cinco seções, a introdução, seção na qual apresentamos o tema central da pesquisa, seguida do referencial teórico no qual se discutirá acerca do contato linguístico, bilinguismo e suas vertentes. Mais adiante, na terceira seção, apresenta-se a metodologia utilizada no estudo, incluindo a delimitação do lócus da pesquisa, um breve resumo histórico e o perfil dos informantes. Na seção quatro, são mostrados os resultados obtidos na pesquisa por meio dos gráficos e as análises feitas acerca da formação bilíngue dos catraieiros. Em seguida apresentam-se as considerações finais e as referências.

\section{Breve histórico dos estudos do contato linguístico}

O contato linguístico sempre esteve presente no desenvolvimento, na formação e na estruturação das línguas, sendo, portanto, um componente determinante no processo de evolução e mudança nas línguas, embora nem sempre os estudos linguísticos o tenham considerado como um fator determinante.

Ainda que estudos isolados do contato tenham ocorrido desde o século XIV, historicamente, o contato linguístico apenas começa a ganhar relevância como fator de mudança nas línguas e nas sociedades no século XIX, quando o método histórico e a gramática comparada abrem caminho para o pensamento linguístico contemporâneo (Leroy, 1971). As noções de parentesco linguístico e de protótipo comum impulsionariam o avanço da linguística, situando-a em uma perspectiva histórica, científica e racionalista. 


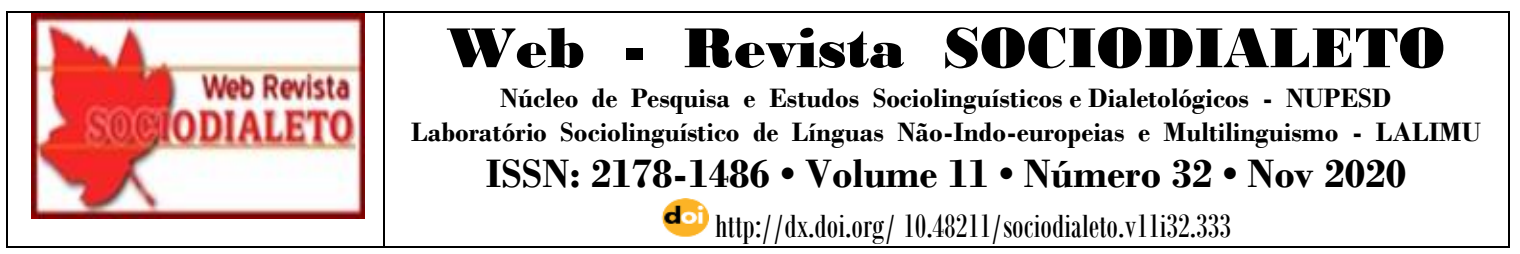

No final dos anos de 1800, a gramática comparada ganha uma nova orientação, abandonam-se as concepções românticas sobre a pureza da língua primitiva e renunciase a análise genética das formas gramaticais. Os chamados neogramáticos, imbuídos na crença absoluta das leis fonéticas, dedicam-se a aplicar rigorosamente o método positivista às mudanças linguísticas, porém, se por um lado as leis fonéticas davam conta de um certo número de modificações ocorridas em certas línguas, em certos lugares, em determinados períodos, por outro, pesquisas linguísticas deste período também iriam mostrar que outras mudanças no campo da semântica ou da sintaxe também poderiam ser constatadas com certa regularidade, embora não tivessem recebido, na época, a mesma atenção dedicada as mudanças sonoras.

Finalmente, foi observando-se que a língua de uma dada localidade está frequentemente acessível à influência de populações com as quais seus membros estão em contato, que se constatou que comunidades linguísticas distintas se emprestam mutuamente palavras, ordens sintáticas, formas gramaticais, modos de pronunciar de outras línguas, de outros falares e mesmo de textos escritos, e que o resultado pode ser, embora por processos diferentes, semelhante aquele das mudanças espontâneas (DAY 2005).

No início do século XX, a Geografia Linguística vai se preocupar em considerar o meio no qual uma determinada língua se insere, estudando a repartição geográfica das formas e das palavras, assim como seu grau de extensão, numa tentativa de traçar os limites dialetais. Para Leroy (1971, p. 50) “as observações feitas sobre a repartição dos falares contribuíram para dar um golpe final no dogma neogramático de 'infalibilidade das leis fonéticas', e concede ao estudo do contato um novo fôlego".

O estudo da repartição geográfica dos fatos fonológicos fez mostrar que várias ocorrências ultrapassam comumente os limites de uma língua e tendem a reunir várias línguas contíguas, independentemente de suas relações genéticas ou da ausência destas relações.

Um dos nomes que se destaca no estudo do contato no início do século XX, ainda que seu trabalho não tenha tido a justa repercussão na sua época, é o de Hugo Schuchardt. 


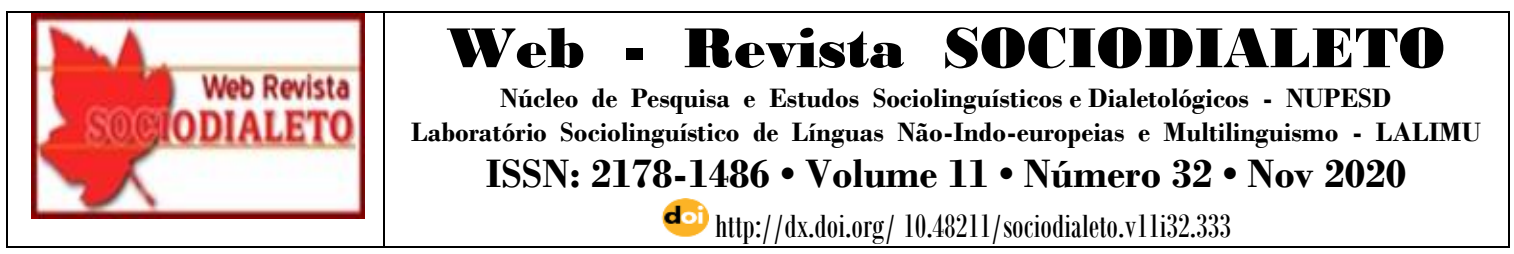

A noção de "Afinidade linguística" por ele defendida, rompe totalmente com o comparatismo genealógico, contesta fundamentalmente sua tipologia e recusa a metáfora darwiniana sobre a qual se fundamenta.

Ainda no século XX, os estudos de contato ganham um espaço significativo com o surgimento da Sociolinguística, que de acordo com Labov (1966, p. 72), "tem como objeto de estudo a reflexão e análise da própria estrutura e da evolução da língua no contexto social da comunidade". A perspectiva sociolinguística permite analisar não somente a relação entre os indivíduos e suas línguas, mas também as relações entre os grupos e colocar em evidência fenômenos tanto individuais quanto sociais decorrentes do contato linguístico.

Um dos primeiros a falar sobre o contato linguístico foi Weinrich (1953). Na sua concepção as línguas entram em contato quando o indivíduo as utiliza alternadamente, a partir da perspectiva da mente do falante bilíngue. Em uma abordagem mais numérica, Calvet argumenta que a quantidade existente de línguas no mundo, faz com que as sociedades sejam, de modo geral, plurilíngues e enfatiza que:

O plurilinguísmo faz com que as línguas estejam constantemente em contato. O lugar desses contatos pode ser o indivíduo (bilíngüe ou em situação de aquisição) ou a comunidade. E o resultado dos contatos é um dos primeiros objetos de estudo da sociolinguística (CALVET, 2002, p.35).

Em outros termos, pode-se afirmar que o quantitativo de línguas, aliado ao intercâmbio sem precedentes entre os povos que se configura nos dias atuais, impulsionado pelos elementos da vida moderna como a mídia e a internet, o comércio internacional e o turismo, faz com que o cidadão de hoje e as sociedades contemporâneas sejam, por definição, plurilíngues (DAY, 2005). Nesse sentido, as regiões de fronteira, por sua vez, dadas as condições geopolíticas em que se encontram, são particularmente fecundas para as situações de contato e, também, para o surgimento de sociedades bi/multilíngues, contexto em que se insere a realização desse trabalho. 


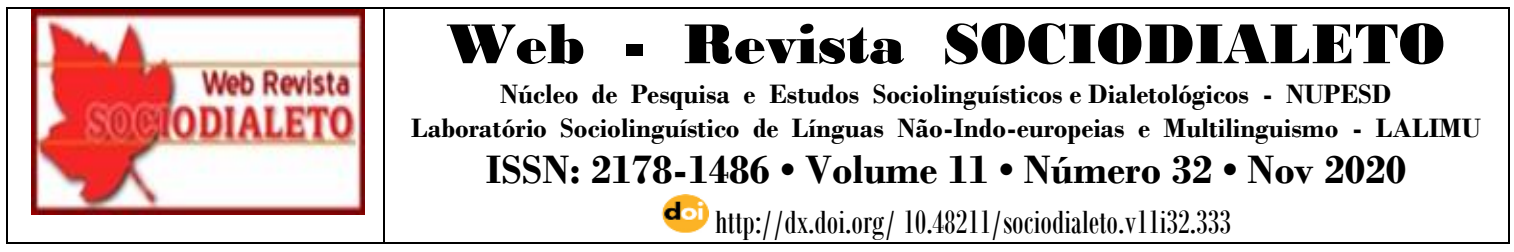

\subsection{Contato linguístico em regiões de fronteira: um campo aberto para o bi/multilinguismo.}

O contato entre línguas é fato comum nas zonas de fronteira política entre países e os fenômenos resultantes do contato interpessoal entre grupos falantes de línguas distintas em espaços contíguos, como é o caso das fronteiras, são bastante diversos. Nessas zonas, o cruzamento contínuo de pessoas traz consigo o encontro de línguas, de culturas e de comportamentos. Nesse sentido, Ganster et al. (1997, p. 376) compreendem que "as regiões de fronteira constituem pontes entre nações, que ajudam a eliminar as barreiras físicas e psicológicas, tornando mais abrangentes as formas de cooperação internacional".

De acordo com Sturza

nas zonas de fronteira, nas quais o contato humano é mais intenso e a mobilidade das populações contribui para intensificar o cruzamento das línguas praticadas, a extensão e o uso das línguas estão constituídos por uma dinâmica muito particular, determinando inclusive uma política de línguas que se organiza neste caso, a partir de um lugar que lhe atribui o falante ( STURZA, 2006, p.35).

Na mesma linha de percepção, Chiappini e Hauck acreditam que "a fronteira converge povos, línguas e culturas que se misturam e, ainda assim, conservam certas características, pois as fronteiras são grandes zonas afetadas de forma diferente, respeitando uma dinâmica própria, de acordo com cada região" (CHIAPPINI; HAUCK, 2011, p. 27).

As línguas, nesse contexto, para além de delimitação da fronteira linguística, atuam tanto no reforço e preservação das identidades e da cultura, quanto se colocam a serviço do encontro, do entendimento e do partilhamento sociocultural e econômico. Em consequência, a eclosão do bilinguismo como fenômeno individual e social é um dos primeiros e mais evidentes resultados do contato linguístico nas áreas de fronteira, tendo relação intrínseca com a história dos povos em presença e o contexto geográfico. 


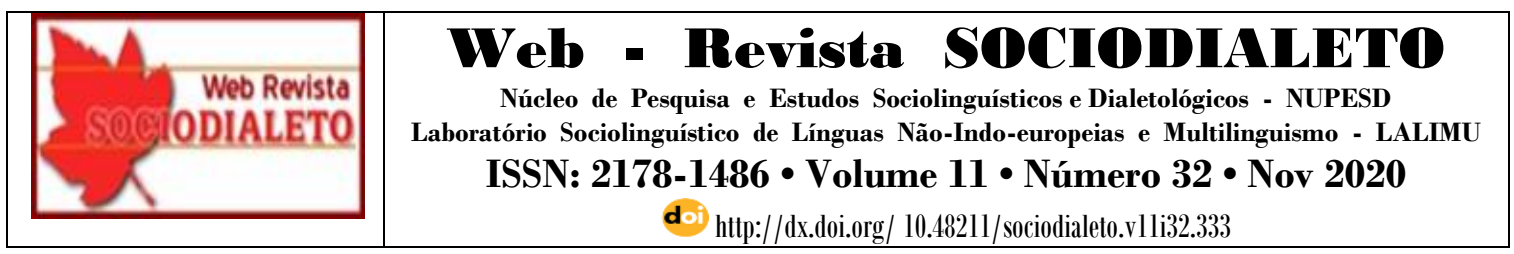

\subsection{Algumas discussões acerca do Bilinguismo}

Os debates em torno da definição de bilinguismo não são recentes e tampouco constituem questão superada ou consenso no universo da linguística.

O bilinguismo teve discussões mais aprofundadas a partir do século $\mathrm{XX}$, quando diversos estudiosos se empenharam em compreender o real sentido da palavra. Em seus estudos acerca do bilinguismo, López (1997, apud GASS; SELINKER, 2008) traz uma definição de bilinguismo que considera a etimologia latina da palavra bi-linguis, segundo a qual, bilíngue é quem fala duas línguas, posto que o prefixo 'bi' significa dois, e ‘linguis' se refere à língua.

Para Bloomfield (1935, apud HAMERS; BLANC, 2000, p.6) o bilinguismo é "o controle nativo de duas línguas". Partindo dessa ideia, Etxebarría (1995, apud MEDINA LÓPEZ, 1997, p. 19) compreende que bilíngue “é o indivíduo que, além de sua própria língua, possui uma competência semelhante em outra língua e é capaz de usar uma ou outra em qualquer situação comunicativa e com eficácia comunicativa idêntica”.

No sentido contrário, em uma concepção mais ampliada de bilinguismo, Edwards (2006) defende que saber ao menos uma palavra em outra língua já pode ser elemento indicativo de uma competência bilíngue.

Por outro lado, dando ênfase à ideia de utilização, Grosjean (1994) baseou o seu conceito no uso constante das línguas, para ele os bilíngues são as pessoas que fazem uso de duas ou mais línguas ou dialetos no seu dia a dia. Neste sentido, o bilinguismo é parte do uso frequente na vida das pessoas, em seu cotidiano. Nessa mesma linha, Haugen (1953, apud HARMERS; BLANC, 2000, p.6) enfatiza que "o bilinguismo corresponderia à habilidade de produzir sentenças completas e com sentido na segunda língua".

Em uma perspectiva semelhante, Day (2005, p. 22-23) considera o bilinguismo como:

A capacidade de uma pessoa, de uma comunidade ou parte dela, de utilizar dois ou mais códigos em diversos domínios ou atividades de sua 


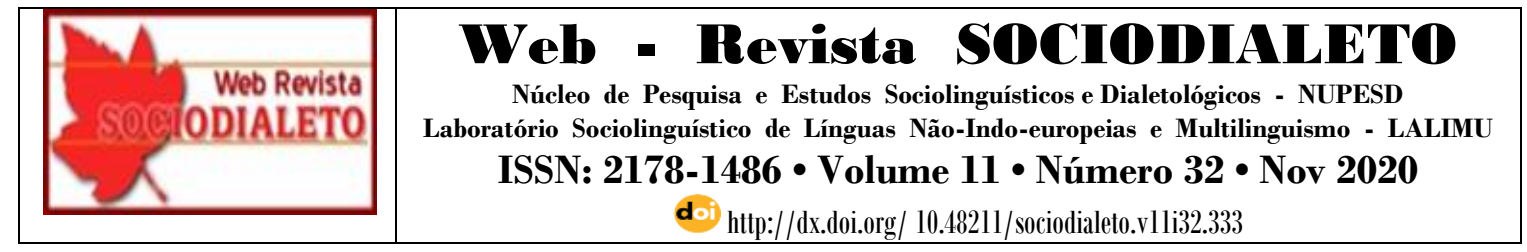

vida cotidiana, família, escola, trabalho. (...) O conhecimento linguístico em cada uma das línguas é adaptado às exigências práticas inerentes aos domínios ou atividades envolvidas e não necessariamente coincidentes com os conhecimentos equivalentes de um falante nativo ideal. (DAY, 2005, p.22-23).

Por fim, alguns teóricos como Bhatia (2006, p. 5, Apud PRESS; ÁLVARES, 2014) afirmam que a investigação acerca do bilinguismo "é uma área ampla e complexa, incluindo o estudo da natureza do conhecimento e uso bilíngue de duas ('ou mais') línguas $[\ldots]$ ".."

\subsubsection{Bilinguismo individual}

Quando se discute acerca do bilinguismo individual deve-se considerar a habilidade do indivíduo de construir enunciados em mais de uma língua, tendo em vista a predominância em uma das quatro competências linguísticas (ler, escrever, falar e escutar). Seguindo esta perspectiva, Mackey (1972, p. 555), define o bilinguismo como "uma característica individual que pode ocorrer em graus variáveis, desde uma competência mínima até um domínio complexo de mais de uma língua”

Mackey (1992, p.46) argumenta que "o bilinguismo é uma estrutura de comportamentos linguísticos, mutuamente modificáveis, com níveis, funções, alternâncias e interferências". Na visão do autor (1992, p. 16-17) o bilinguismo individual é resultante "não apenas do tempo gasto na prática de cada idioma, mas também da distribuição das funções do idioma".

Mackey (1992) frisa ainda que o bilinguismo individual só pode ser compreendido se forem levados em conta alguns fatores, que em sua visão são essenciais, tais como: 1) o grau de proficiência, 2) o conhecimento que a pessoa tem sobre as línguas, 3) a função exercida por elas no seu dia a dia bem como a alternância de códigos, isto é, a frequência com que o falante muda de uma língua para outra no seu cotidiano. 


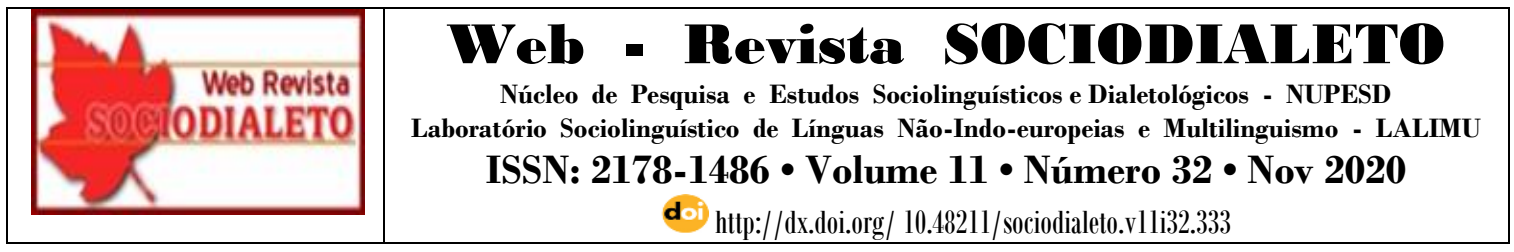

Levando em consideração esses critérios considerados na definição de bilinguismo individual, há, ainda, vários motivos que estimulam a formação bilíngue do indivíduo. Para Grosjean (1994, p.165):

Os bilíngües adquirem e usam suas línguas com diferentes propósitos, em diferentes situações de vida e com diferentes pessoas. Isso acontece precisamente porque as necessidades e usos das línguas são normalmente muito diferentes e os bilíngües raramente desenvolvem a mesma fluência nas duas línguas. O nível de fluência atingida numa língua (mais precisamente numa habilidade lingüística) dependerá da necessidade de uso daquela língua e será específica ao domínio (casa, trabalho, escola, etc.). (GROSJEAN, 1994, p.165).

Nesse sentido, da mesma maneira que se modifica o lugar em que o bilíngue precisa fazer o uso de mais de uma língua em interação com um falante estrangeiro, a competência linguística desse indivíduo também irá se adequar à necessidade de utilização de alguma habilidade linguística específica, seja ela de leitura, escrita, fala ou escuta no outro idioma.

Mackey (1976, p. 85) argumenta que "o comportamento bilíngue é simplesmente o meio de substituir um idioma por outro como uma ferramenta de comunicação interna e externa para a comunidade". Nesse sentido, Hammers e Blanc (1983, p.183) enfatizam que a característica principal dessa interação interpessoal existente na formação do bilíngue é a adaptação do discurso do locutor ao interlocutor e vice-versa. E essa característica pode ser analisada em qualquer interação em todos os níveis linguísticos. Porém, Mackey salienta que

"o indivíduo que está em contato com vários idiomas não consegue têlos inteiramente. Existem indicações segundo as quais certos bilíngues aplicam inconscientemente medidas econômicas lexicais, limitando-se, tanto quanto possível, a termos de alta valência, termos que as pessoas envolvidas podem usar para designar um máximo de significados, uma vez que são obrigados a manter em sua memória um vocabulário duplo" (MACKEY, 1976, p.221). 


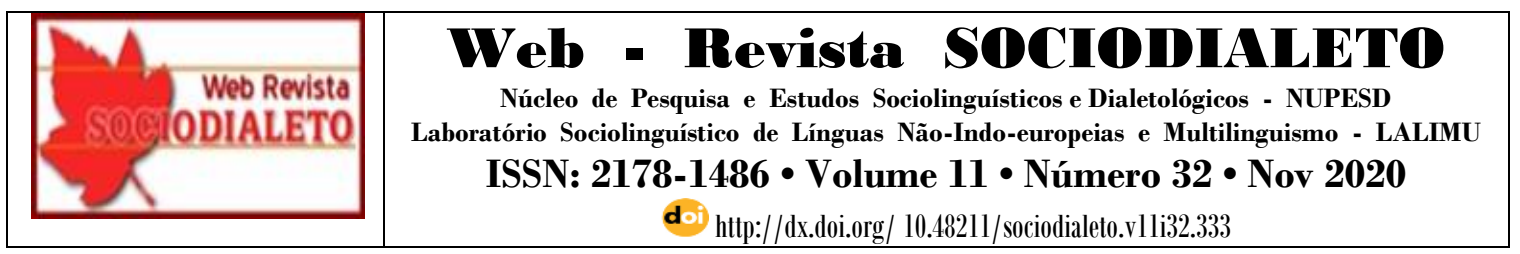

Nesse sentido, vale destacar que ao tratar da bilingualidade, termo designado pelos autores ao bilinguismo individual, Hamers e Blanc (2000, p. 25-30) levam em consideração seis dimensões: 1) Competência relativa; 2) Organização cognitiva; 3) Idade de aquisição/aprendizagem; 4) presença ou não de indivíduos falantes da L2 no ambiente em questão; 5) status das duas línguas envolvidas; e 6) identidade cultural, porém, tais conceitos não serão desenvolvidos nesse trabalho, posto que a discussão central é o bilinguismo analisado do ponto de vista do grupo social, conforme discussão a seguir.

\subsubsection{Bilinguismo Societal}

As sociedades bilíngues ou multilíngues não surgem por acaso ou capricho, elas são fruto do contato entre grupos linguísticos distintos e da necessidade de comunicação. Segundo Appel \& Muysken (1996), existem mais de 5 mil línguas no mundo e cerca de 190 países, assim sendo, o contato linguístico é inevitável e em decorrência, há várias comunidades linguísticas que vivenciam o bilinguismo societal. Partindo dessa perspectiva, para Preuss e Álvares (2014, p.404) o bilinguismo societal é considerado como o "uso de duas línguas em uma determinada comunidade".

Day (2005, p. 33) considera que de modo geral "o bilinguismo social é fruto da convivência de pessoas que dividem o mesmo espaço geográfico, onde um grupo aprende a língua do outro e muitas vezes acaba por compor um único grupo social bilíngue”, ou mesmo grupos bilíngues distintos.

Considerando a distribuição espacial, Leclerc (2002, apud Day, 2005) identifica dois tipos de sociedade multilíngues segundo o espaço em que se encontram: sociedades bilíngues com coabitação social, em que comunidades distintas ocupam o mesmo espaço e usam línguas diferentes e as sociedades bilíngues sem coabitação social, em que uma única sociedade faz uso de duas línguas distintas, a língua materna e uma língua veicular.

Hamers \& Blanc (1989) propõem uma diferenciação semântica entre os termos bilinguismo e bilingualidade, em que o primeiro faz referência ao grupo social bilíngue e o segundo corresponde ao uso individual de duas ou mais línguas. Entretanto, Romaine 


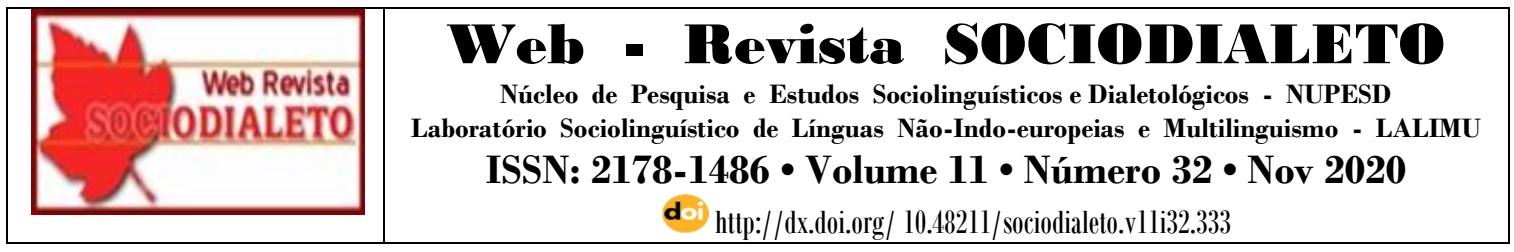

(1997) assinala que não se pode separar a definição de bilinguismo societal do individual, pois, tanto em comunidade quanto individualmente ambos se expressam em mais de um idioma.

De acordo com Mackey (1992, p.45)

Os problemas dos indivíduos bilíngues não são idênticos aos das populações bilíngues, e os últimos não são os mesmos do bilinguismo institucional(...). Em cada categoria devemos distinguir os vários tipos de níveis linguísticos e funções linguísticas.

Ainda nessa linha de entendimento, ao discutir o bilinguismo societal, Weinreich (1953) enfatiza que não se pode observar o bilinguismo apenas da perspectiva individual, pois deve-se levar em conta as habilidades linguísticas de todos os falantes de uma determinada comunidade que se expressam em mais de uma língua, tal qual ocorre muito comumente nas zonas de fronteira.

Altenhofen (2004), por sua vez, aponta graus diferenciados de bilinguismo societal. Para ele o grau de bilinguismo irá variar dependendo da quantidade e da periodicidade com que o falante bilíngue usará cada uma das línguas em presença, com isto, em uma sociedade, nem todos terão o mesmo grau de bilinguismo e tampouco poderão ser considerados bilíngues equivalentes.

De acordo com Day (2005), fatores diversos compõem os processos de formação de sociedades bilíngues ou multilíngues, dentre os quais destacam-se a colonização e ocupação militar, o intercâmbio comercial, a superioridade demográfica entre comunidades linguísticas, o poder e prestígio de uma língua nas relações intergrupais, o sistema educacional, a religião, os meios de difusão e, especialmente no âmbito desse trabalho, a situação geopolítica de uma comunidade linguística, como ocorre no caso das fronteiras, a influência econômica e o movimento migratório.

Weinreich (1970, apud Day, 2005) destaca o fato de que em toda situação de contato, as linhas divisórias que separam povos falantes de diferentes línguas maternas são coincidentes com outras divisões de natureza não linguística relacionadas a aspectos 


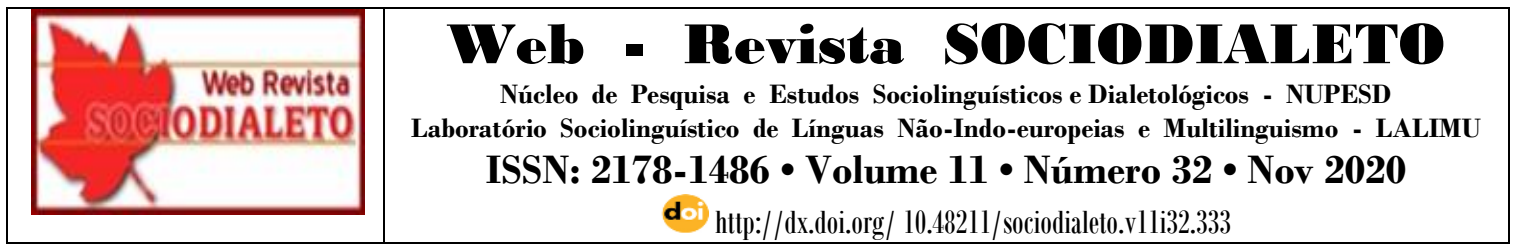

étnicos, raciais, religiosos, econômicos e de status social. A linha geográfica é, portanto, só mais um dos fatores de convergência na organização social e linguística de povos. Nesse sentido, o autor considera que, no caso de uma região de fronteiras, salvo em casos de obstáculos físicos, o contato linguístico é fator inerente ao contexto e conduz ao bilinguismo individual e societal.

Outro fator importante na conformação de sociedades bilíngues que se mostra relevante para o trabalho aqui proposto é a força relativa de uma língua sobre outra quanto ao poder econômico que supõem. Especialmente em situações fronteiriças, as expectativas de trabalho e de melhores condições de vida conduzem frequentemente ao uso de uma nova língua, cujo prestígio pode trazer resultados econômicos mais vantajosos. De igual maneira, o valor econômico influencia diretamente nos processos migratórios dos povos e, por conseguinte, afetam diretamente a condição monolíngue dos indivíduos, conforme discutiremos nas próximas seções deste trabalho.

\section{$3 \quad$ Aspectos metodológicos da pesquisa}

Este trabalho caracteriza-se como uma pesquisa de campo, descritiva e quantiqualitativa, realizada no município de Oiapoque, no estado do Amapá. O público alvo é o dos trabalhadores catraieiros que trabalham diariamente nessa zona fronteiriça. A pesquisa de campo teve como instrumentos de coleta de dados o questionário e a entrevista semiestruturada.

Visando compreender o processo de formação bilíngue desse público específico, no âmbito do contato linguístico português-francês na fronteira, foram entrevistados 20 catraieiros que trabalham diariamente no fluxo de catraias na fronteira franco-brasileira, todos homens, pois não foram encontradas mulheres exercendo a atividade. A coleta de dados consistiu em três momentos: (1) abordagem, solicitação e consentimento do informante, (2) resposta ao questionário sociolinguístico e (3) a entrevista propriamente dita. 


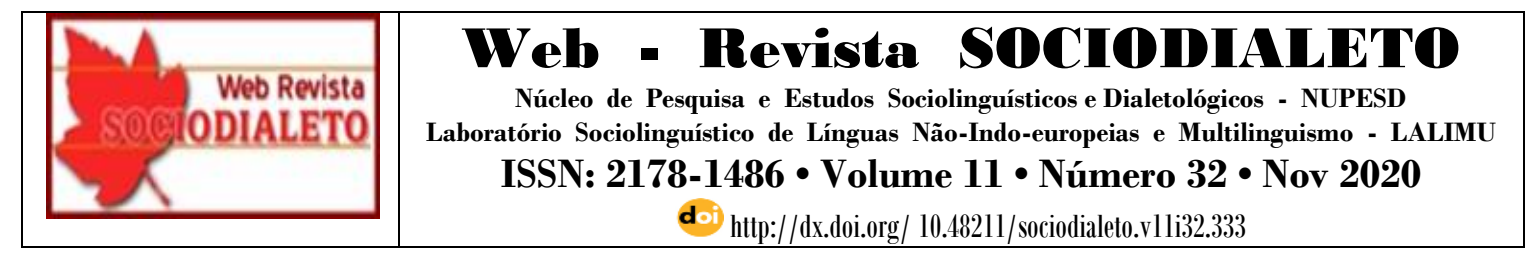

A partir do questionário sociolinguístico, elaborou-se o perfil dos informantes e com as entrevistas foi possível constatar algumas influências do contato linguístico no grupo pesquisado.

As perguntas pré-elaboradas que conduziram a entrevista foram as seguintes: 1) qual a principal língua da fronteira? 2) quantas línguas você fala? e quais 3) qual língua é mais utilizada no ambiente de trabalho? 4) qual delas você fala melhor (ou se sente mais confortável em falar)? 5) como a (s) aprendeu? 6) você achou difícil aprender uma outra língua? 7) você escreve em outra língua? e 8) de que modo essa língua influencia/influenciou na sua primeira língua?

\subsection{A fronteira lócus da pesquisa}

A pesquisa teve como lócus o município de Oiapoque, na região de fronteira entre o Brasil e a Guiana Francesa. Oiapoque é um município brasileiro pertencente ao estado do Amapá, criado através da Lei no 7.578, do dia 23 de maio de 1945, que fixa a divisão político - administrativa do território brasileiro com o território francês.

O município é banhado pelo rio Oiapoque que começa na serra do Tumucumaque e deságua no oceano atlântico. Essa divisa, no entanto, só foi estabelecida no ano de 1913 através do Tratado de Utretcht, quando se determinou o limite fluvial entre as fronteiras do Brasil (Oiapoque) e da França (Saint-Georges na Guiana Francesa).

Atualmente, estima-se que o contingente populacional do Oiapoque é, segundo informações do site do IBGE (2019), de cerca de 27. 270 habitantes. A região constitui uma área fronteiriça com bastante fluxo migratório de ambas as partes, tendo como base uma diversidade de línguas e culturas, dentre elas o português, o francês, diferentes falares indígenas e um crioulo de base francesa.

Saint-Georges, no lado oposto, é uma pequena comunidade da Guiana Francesa, oficialmente criada em 1946, situada a $189 \mathrm{~km}$ da capital do departamento, Caiena, na 


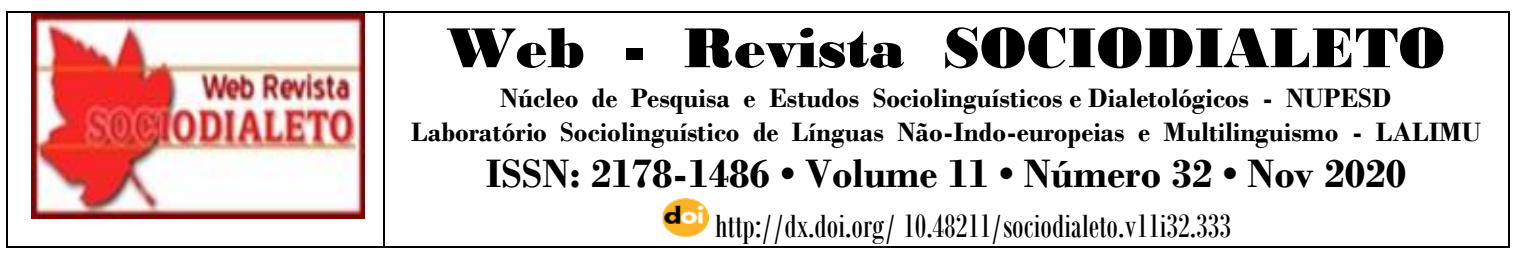

margem esquerda do rio Oiapoque. De acordo com o INSEE ${ }^{4}$, Saint-Georges tem uma população de cerca de 4.000 habitantes.

Em que pese a abertura recente da ponte binacional ocorrida em 2017, o meio de transporte mais habitual utilizado para travessia entre as fronteiras é a catraia, um barco de pequeno porte capaz de comportar entre quatro e dez passageiros por viagem com duração de 10 a 15 minutos. Esse transporte fluvial é conduzido pelos barqueiros conhecidos ali na região como catraieiros, cuja condição bilíngue constitui o eixo de investigação principal desta pesquisa.

\subsection{Perfil dos informantes da pesquisa}

Nesta seção apresenta-se o perfil dos informantes deste estudo. Como já mencionado na seção anterior, o público-alvo deste trabalho são os catraieiros, condutores das embarcações denominadas catraias e responsáveis por fazer a travessia entre as fronteiras (brasileira e francesa) nesse tipo de transporte. Durante o período em que foi realizada a pesquisa, pode-se notar que os catraieiros também se denominam como marinheiros e pilotos fluviais, eles fazem uso também de uniformes, cada um pertencente a um grupo de trabalho ou associação, tanto de Oiapoque quanto de Saint - George.

Foram entrevistados vinte catraieiros na faixa etária entre 20 e 60 anos. A metade dos informantes $(50 \%)$ reside no município de Oiapoque há bastante tempo, no entanto, não nasceram lá, são oriundos de municípios vizinhos ou de outros estados como o Pará, Maranhão e Piauí.

De acordo com os próprios informantes, eles vieram morar no município pela vantagem de ser uma zona de fronteira entre dois países, onde o fluxo corrente de duas moedas, nesse caso o real e o euro, oferece maiores condições de renda porquanto essa segunda moeda vale cerca de cinco vezes o valor da primeira, o que, segundo eles, favorece a economia do lado brasileiro.

\footnotetext{
4 Instituto Nacional de Estatística e de Estudos Econômicos. Disp. em https://www.insee.fr/fr/statistiques/3675727
} 


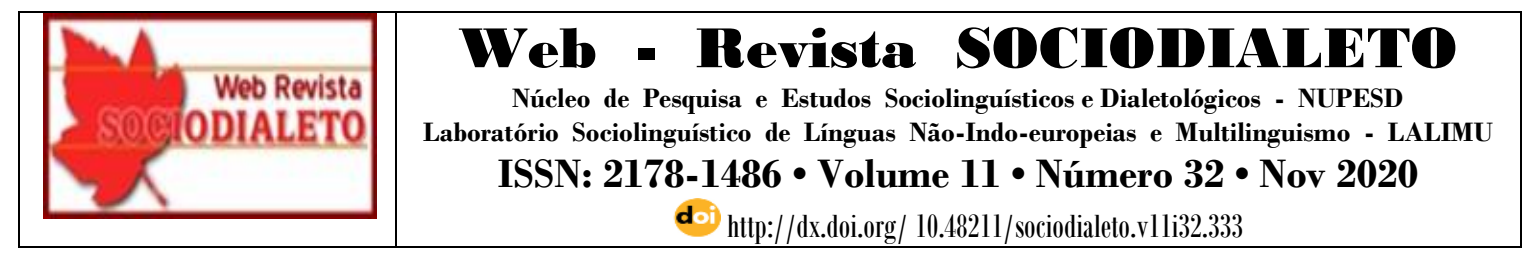

Constatou-se que grande parte dos informantes trabalha todos os dias, com frequência mais acentuada nos turnos matutino e vespertino (70\%), período em que a travessia é mais frequente, porém, ainda assim, um percentual importante (30\%) trabalha mesmo durante a noite no trajeto entre Oiapoque (ponto principal de concentração dos catraieiros) e Saint-Georges.

Em decorrência da entrada e saída de estrangeiros e de brasileiros na fronteira, os catraieiros faturam mensalmente entre 1.244 (mil duzentos e quarenta e quatro reais) e 4.000 (quatro mil reais), dependendo da época do ano. Os dados apontam que a ampla maioria recebe mais de dois salários mínimos por mês, razão pela qual, eles se consideram pessoas privilegiadas pela possibilidade de ter uma renda maior do que teriam em circunstâncias semelhantes em outras regiões do Brasil, ganhando em real ou em euro, o que garantiria, consequentemente, uma qualidade de vida melhor.

Em relação à escolaridade dos informantes, a maior parte estudou integralmente em escola pública, sendo que muitos não concluíram o ensino fundamental (45\%), nem o ensino médio (40\%), o que eles justificam pela a necessidade de começar a trabalhar muito cedo para ajudar a família e que posteriormente se tornaram a pessoa mais importante a contribuir com o sustento dos familiares, fazendo com que o trabalho passasse a ser essencial na renda familiar.

Quando se trata da vivência na fronteira, todos os catraieiros, como já era de se esperar, informaram que conhecem bem a fronteira francesa (Saint - Georges), sendo que $60 \%$ dos informantes declararam ter familiares residentes no lado oposto, sendo eles pais, filhos, irmãos, tios ou sobrinhos.

Vale destacar que estes dados são relevantes para a compreensão do bilinguismo desse grupo no que concerne especialmente ao tempo e a frequência do contato, além de aspectos relativos a motivação e circunstâncias do falar bilíngue.

\section{Apresentação e discussão dos resultados}




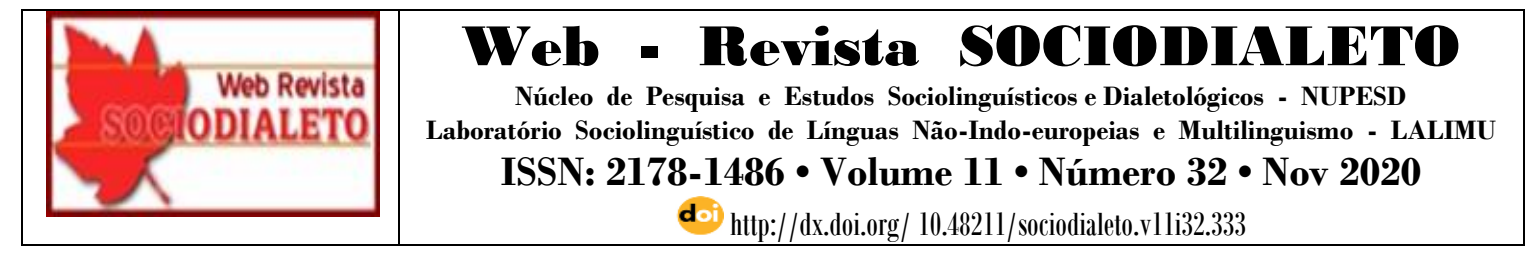

Nesse tópico, serão analisados os dados obtidos na entrevista semiestruturada acerca do contato português/francês na fronteira e o processo de bilinguismo dos catraieiros nesse cenário.

Partindo do parâmetro que o bilinguismo social nasce comumente da convivência entre falantes de línguas distintas no mesmo território ou espaços contíguos e tendo em vista a variedade de línguas que circulam na zona de fronteira de Oiapoque e SaintGeorges, bem como a relação de força que se estabelece entre as línguas (Mackey, 1972), a questão inicial "qual a principal língua da fronteira" aponta razões para a conformação bilíngue dos catraieiros da região de Oiapoque. A língua francesa aparece como mais importante para $40 \%$ do grupo pesquisado, seguida da língua portuguesa, que é a principal língua para $35 \%$ do grupo e o crioulo guianense que surge como a principal para $25 \%$ dos entrevistados, conforme dados apresentados no gráfico 01, a seguir:

\section{Gráfico 01 - Principal língua da fronteira}

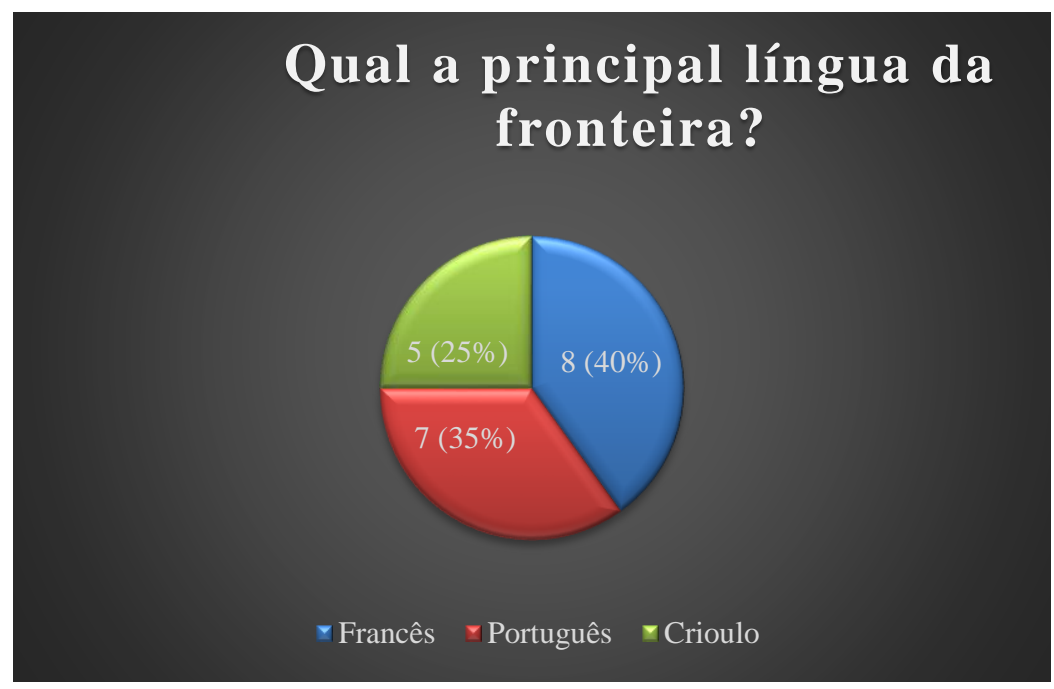

Fonte: Elaborado pelas autoras

Observa-se pelo gráfico 01 que três línguas se destacam no grau de importância para os catraieiros: o francês, o português e o crioulo (guianense). Este dado indica também o uso de pelo menos duas línguas no ambiente de trabalho desses trabalhadores, seja o português e o francês, o português e o crioulo guianense, seja o português, o francês e o crioulo. Destaca-se ainda que na correlação de força entre as línguas, embora o português seja a língua da maioria demográfica, ao francês e ao crioulo guianense se 


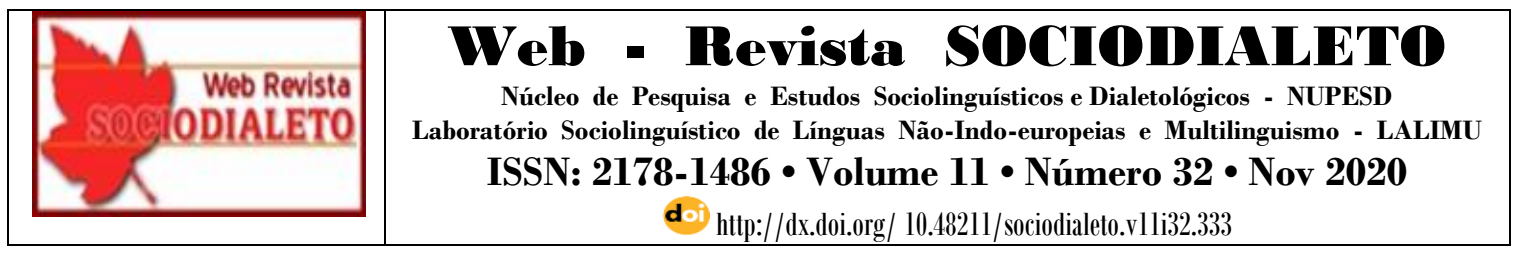

associa o poder econômico que o euro agrega a estas línguas, razão que justifica, inclusive a presença de catraieiros oriundos de outras regiões do país, conforme dados do questionário socioeconômico.

Corroborando os dados acima, no que concerne ao número de línguas faladas pelos catraieiros, constatou-se que a maioria dos entrevistados (45\%) fala três ou quatro idiomas, $35 \%$ deles fala duas línguas e que apenas $20 \%$ deles falam somente o português, estes, geralmente, são os mais idosos.

Segundo os informantes, o uso de duas ou mais línguas se deve ao fato de que seus clientes, em grande parte, são estrangeiros (franceses metropolitanos e guianenses) e como a maioria deles não sabe falar a língua portuguesa, geralmente procuram os catraieiros que sabem falar o francês ou o créole para se comunicar, ou até mesmo pedir informações sobre a fronteira. O gráfico 02 apresenta a compilação das respostas.

\section{Gráfico 02 - No de línguas faladas pelos catraieiros}

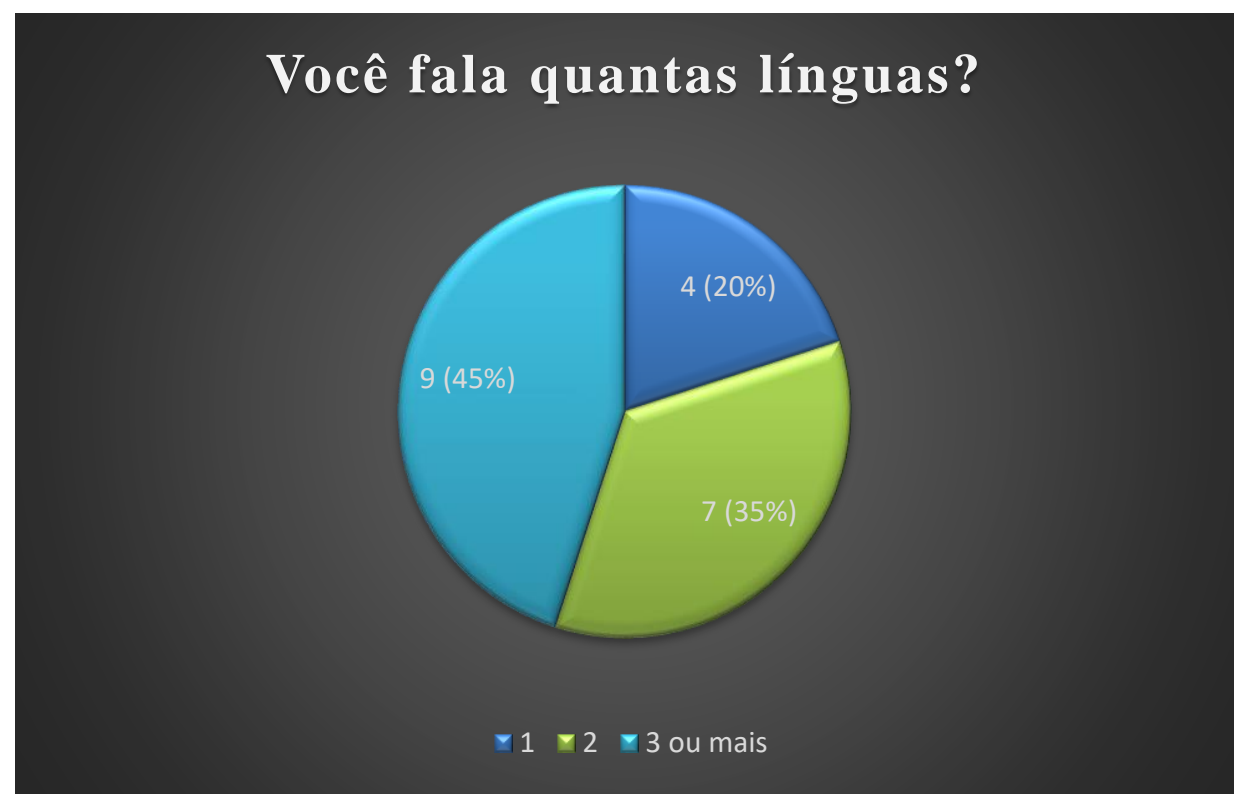

Fonte: Elaborado pelas autoras

O gráfico acima apresenta um quadro bastante significativo quanto ao nível de bilinguismo entre os catraieiros da fronteira, indicando que $80 \%$ deles são bilíngues e falam entre duas e três línguas. Embora não tenha sido possível aferir o nível de domínio 


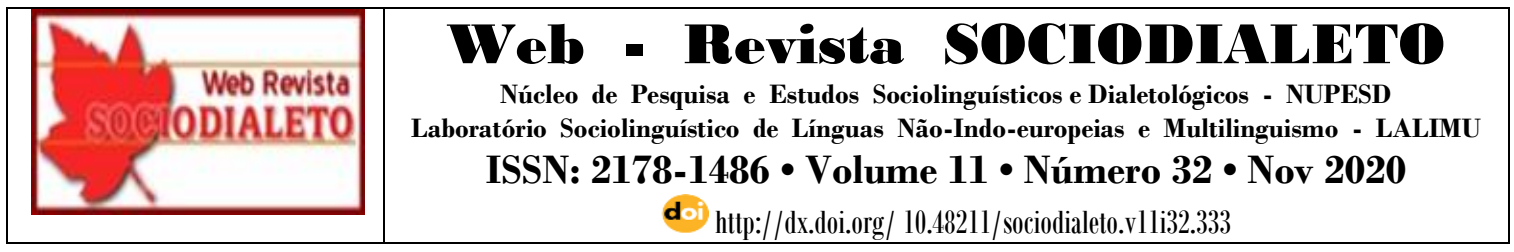

linguístico dos participantes da pesquisa, muitos deles admitem que em muitos casos, o repertório linguístico nas outras línguas (adicionais) é restrito ao universo do trabalho.

Um fator relevante em relação à escolaridade dos entrevistados é que dos vinte envolvidos na pesquisa, metade (50\%) não chegou a estudar nenhum idioma na escola, em contrapartida, a outra parte $(50 \%)$ teve o contato com uma língua estrangeira na escola e a disciplina mais citada foi a língua francesa, seguida da inglesa e da espanhola. No entanto, o conhecimento que têm da língua não é relacionado, por eles, ao estudo formal, mas à vivência diária na fronteira, sobretudo quando se trata do crioulo guianense.

Mediante a essas constatações, perguntou-se aos catraieiros qual das línguas presentes na zona de fronteira (Oiapoque /Saint-Georges) eles mais utilizam para se comunicar no trabalho. Os dados reunidos no gráfico 03 mostram que 50\% dos catraieiros faz uso mais frequente do Português no seu ambiente de trabalho, em seguida, a língua francesa aparece como mais utilizada para $42 \%$ do grupo e por último constata-se o crioulo com $8 \%$ de uso no trabalho pelos informantes.

Estabelecendo um contraponto com a primeira questão, observa-se que embora o francês seja a língua considerada mais importante economicamente, o português ressurge como a língua mais usada na região, uma vez que é seguramente a língua da maioria da população. Nesse contexto, o que se constata, portanto, é um processo frequente de adaptação do discurso (HAMMERS E BLANC, 1983) dos brasileiros para atender aos seus interlocutores franceses, impulsionada pela condição econômica. Em outros termos, pode-se afirmar que a condição bilíngue dos catraieiros é impulsionada pelo aspecto econômico.

\section{Gráfico 03 - Língua mais utilizada no trabalho}



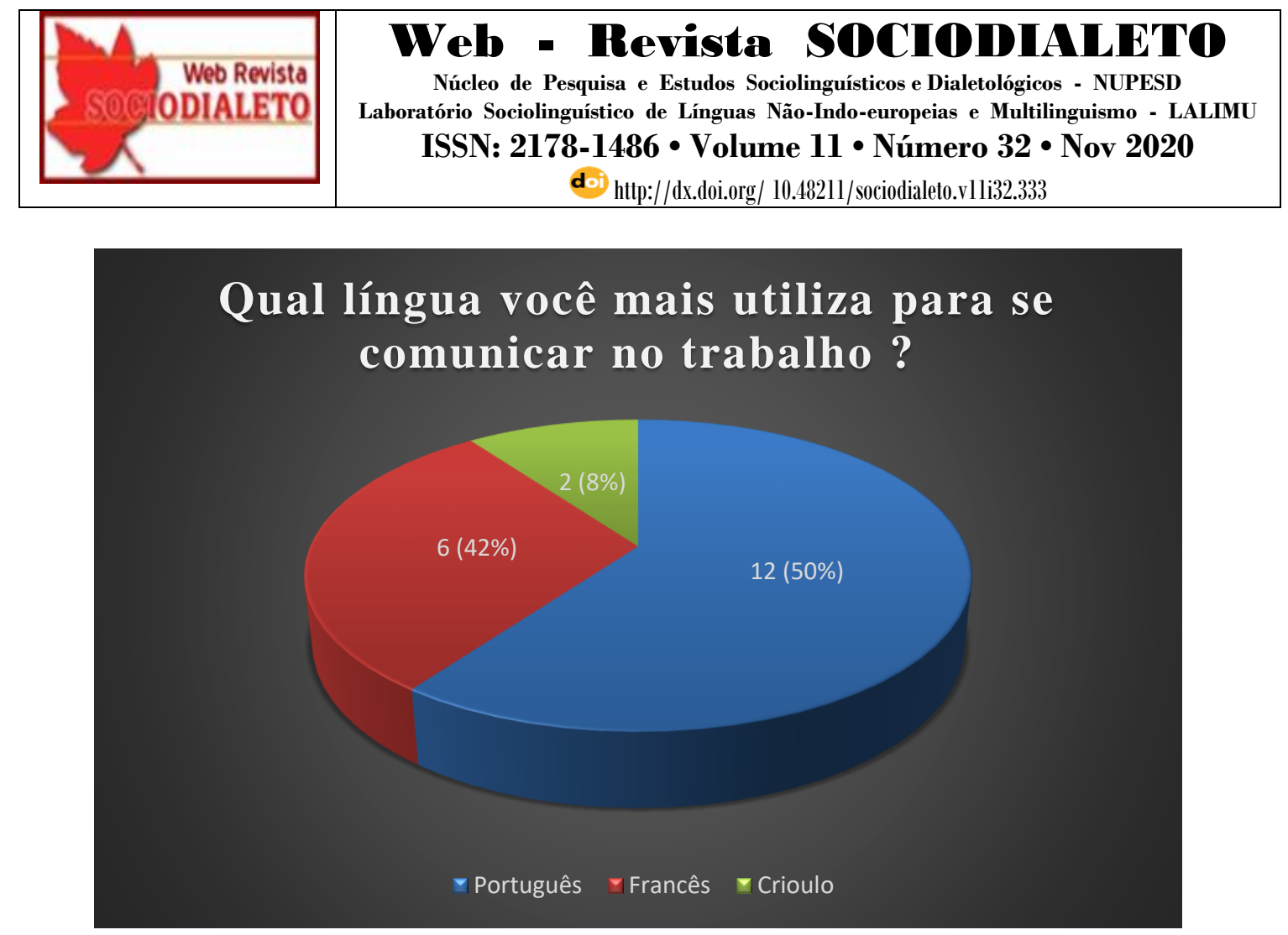

Fonte: Elaborado pelas autoras

Quanto ao domínio e ao conforto linguístico no uso das línguas, por mais que os catraieiros falem mais de uma língua, o gráfico 04 mostra que a grande maioria (70\%) se sente mais confortável em falar o português por ser a sua língua materna e portanto, ter uma fluência maior nessa língua. Por outro lado, $30 \%$ considera o francês como a língua que fala melhor, conforme demostra-se no gráfico abaixo:

\section{Gráfico 04 - Conforto Linguístico}



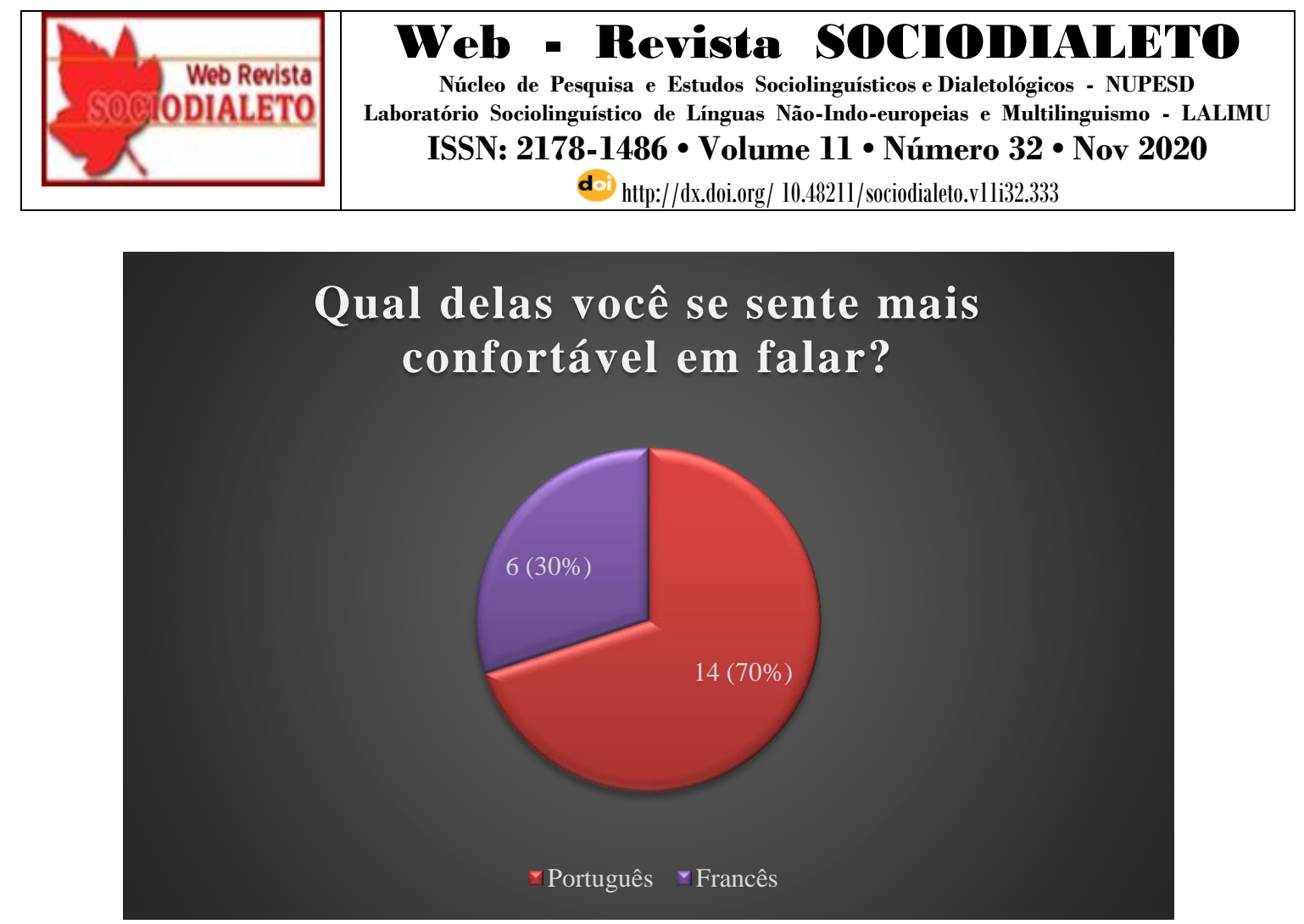

Fonte: Elaborado pelas autoras

O conforto linguístico indicado pelos catraieiros aponta pistas das habilidades linguísticas destes falantes nos idiomas da região e conforme indica Altenhofen (2004), coloca em destaque que nem todos tem o mesmo nível de bilinguismo, de repertório e provavelmente, não alcançam o mesmo nível de bilingualidade (HAMERS E BLANC, 2000). Além disso, outro fator importante na condição bilíngue dos catraeiros está relacionada ao fato de que alguns são originários da região de Oiapoque e provavelmente cresceram convivendo com as línguas majoritárias e, portanto, tem uma convivência muito mais longa com o francês e o crioulo, além do português, o que justifica uma maior habilidade no francês, por exemplo. No sentido oposto, nenhum dos informantes indicou o crioulo como língua de maior conforto linguístico, ainda que alguns deles vejam nessa língua uma grande importância regional. Esse distanciamento pode estar relacionado a questões identitárias e de representação das línguas menos prestigiadas.

Questionados quanto ao processo de tornar-se falante de uma segunda ou terceira língua (L2), questionou-se como os informantes aprenderam as línguas faladas por eles. O gráfico 05 , mostra que esse grupo as aprendeu principalmente em decorrência da convivência com os estrangeiros no seu ambiente de trabalho (85\%), e apenas $15 \%$ informa ter vivenciado processos de aprendizagem formal (escola) ou de aquisição precoce (na infância em família), como se observa no gráfico 05, a seguir: 


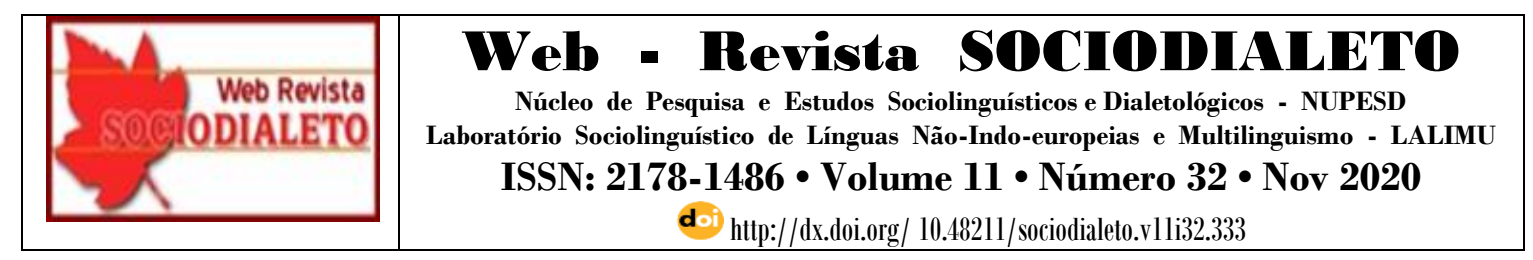

\section{Gráfico 05 - Natureza do falar bilíngue dos catraieiros}

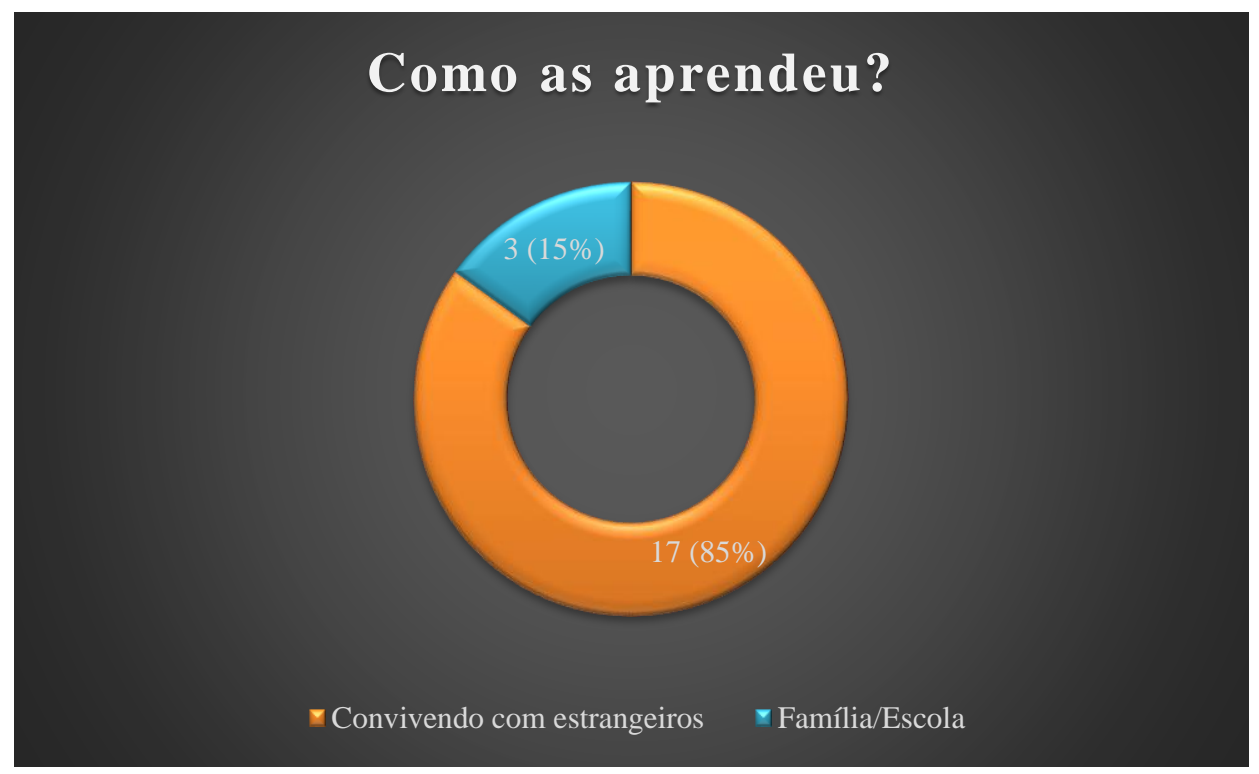

Fonte: Elaborado pelas autoras

Os dados indicam que a conformação bilíngue dos catraieiros é essencialmente fruto do contato linguístico que se dá no ambiente de trabalho e indica uma natureza instrumental, baseada na necessidade de aferir benefícios econômicos. Diferente de outras regiões, onde o bilinguismo português/francês é fruto da aprendizagem formal e principalmente de situações elitizadas de uso, o falar bilíngue dos catraieiros da região de Oiapoque é proveniente da convergência geopolítica, social e linguística de brasileiros e franceses nessa zona de fronteira.

Em complemento a pergunta anterior, o questionamento relativo às dificuldades encontradas nesse processo visava compreender como os informantes perceberam a aquisição dessa(s) nova(s) língua(s). De acordo com o gráfico 06, constata-se uma equivalência nos resultados, $50 \%$ revela que não encontrou dificuldade em aprender uma nova língua, mas em contrapartida, outros $50 \%$ dos catraieiros informam que sentiram dificuldade em aprender esse novo idioma e argumentam que isto só foi possível através do contato diário e pela necessidade de entender o que os clientes falavam, para poder haver uma comunicação entre catraieiros e estrangeiros.

Além disso, alguns informantes afirmam que quando não era possível a comunicação oral, eles optavam por duas estratégias: 1) uma comunicação gestual com o 


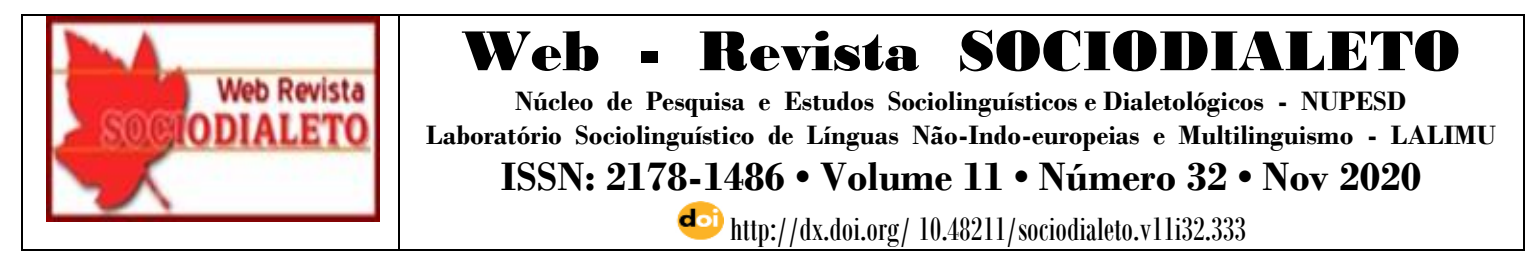

cliente e caso essa primeira não fosse bem-sucedida, 2) eles procuravam, geralmente entre eles, alguém que soubesse falar a língua estrangeira em questão para poder negociar o valor da travessia. $\mathrm{O}$ gráfico 06 retrata a percepção dessa dificuldade.

Gráfico 06 - Dificuldades no processo de aquisição da L2

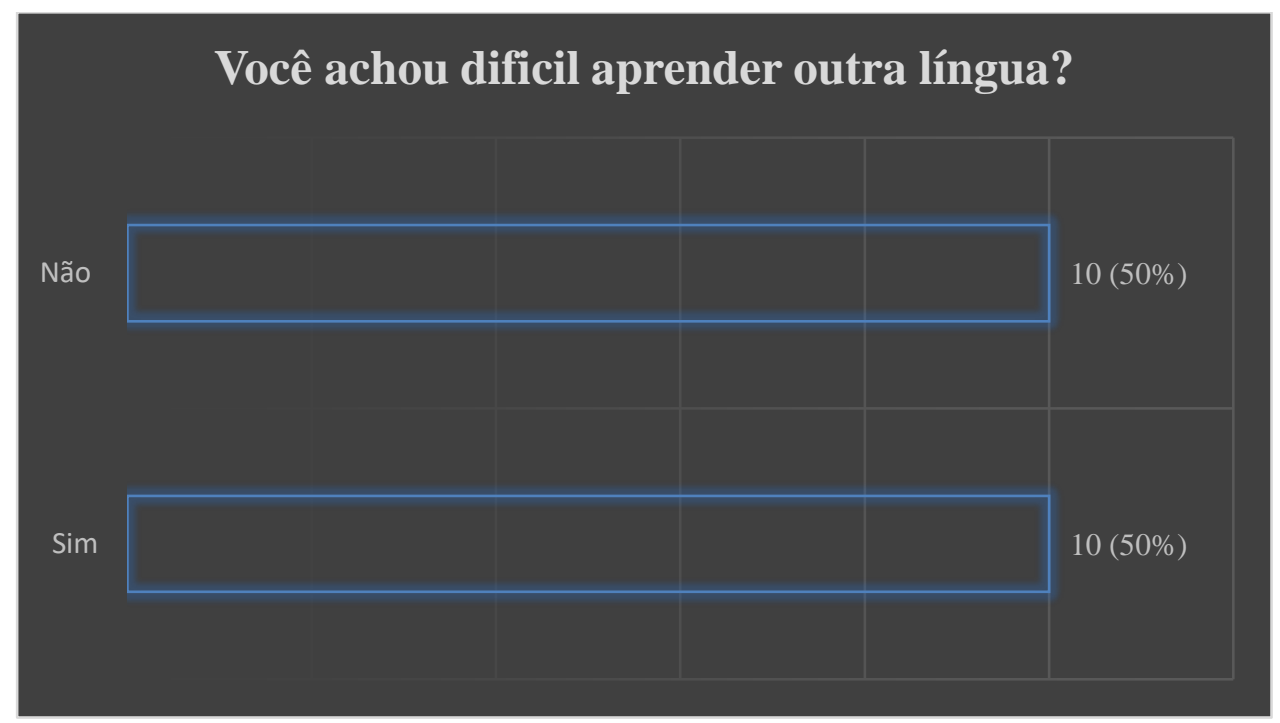

Fonte: Elaborado pelas autoras

Uma vez constatado o uso de mais de duas línguas pela maioria dos catraieiros e considerando o bilinguismo como resultante também das funções do idioma no quotidiano do indivíduo, conforme defende Mackey (1992), buscou-se com a questão 07, compreender se o bilinguismo desse grupo se estenderia para além da competência oral (compreensão e expressão), uma vez que alguns estudiosos entendem que para ser considerado bilinguismo de fato existem níveis de bilinguismo que associam bem mais que falar a língua.

Neste sentido, questionamos aos entrevistados se além de falar um outro idioma, os falantes escreviam nessas línguas. Os dados informam que $20 \%$ dos catraieiros escrevem em sua segunda língua, na oportunidade citam o francês como a língua em que possuem conhecimento da escrita. Os outros $80 \%$ dos informantes não possuem domínio da competência escrita. Como observa-se no gráfico 07, a seguir:

\section{Gráfico 07 - Domínio da escrita da $2^{a}$ língua}



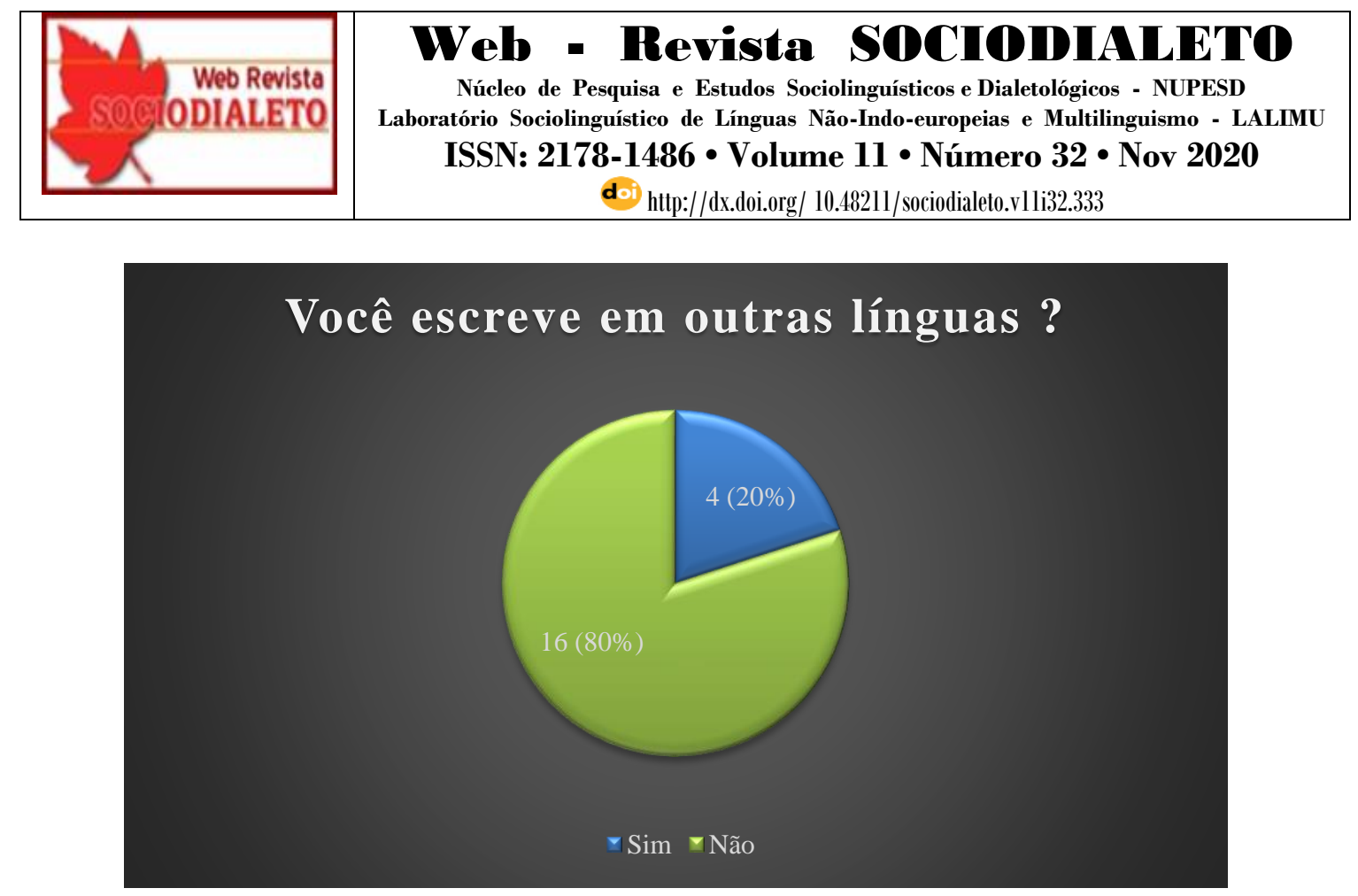

Fonte: Elaborado pelas autoras

Em consonância com as ideias de Grosjean (1994), pode-se dizer que o bilinguismo desse grupo está diretamente vinculado às necessidades específicas e domínios de uso. A competência escrita, pouco exigida nesse contexto, parece ser menos representativa que a oralidade e retrata uma realidade comum de processos de bilinguismo que não estão vinculados ao ensino formal, bem como ocorre com a própria língua materna, vale lembrar que boa parte do grupo não possui o ensino fundamental completo.

Tendo em vista uma possível utilização frequente de uma segunda língua no ambiente de trabalho, considerou-se relevante investigar se esse uso diário da língua estrangeira, na percepção dos informantes, influenciou/ influencia na língua materna dos catraieiros. Os dados apresentados no gráfico 08, mostram que 85\% dos informantes acreditam que a segunda língua interfere significativamente em suas línguas maternas. Somente $15 \%$ acha que as línguas não influenciaram em nada na primeira língua, conforme observa-se no gráfico 08 :

\section{Gráfico 08 - Influência da segunda língua sobre a língua materna}



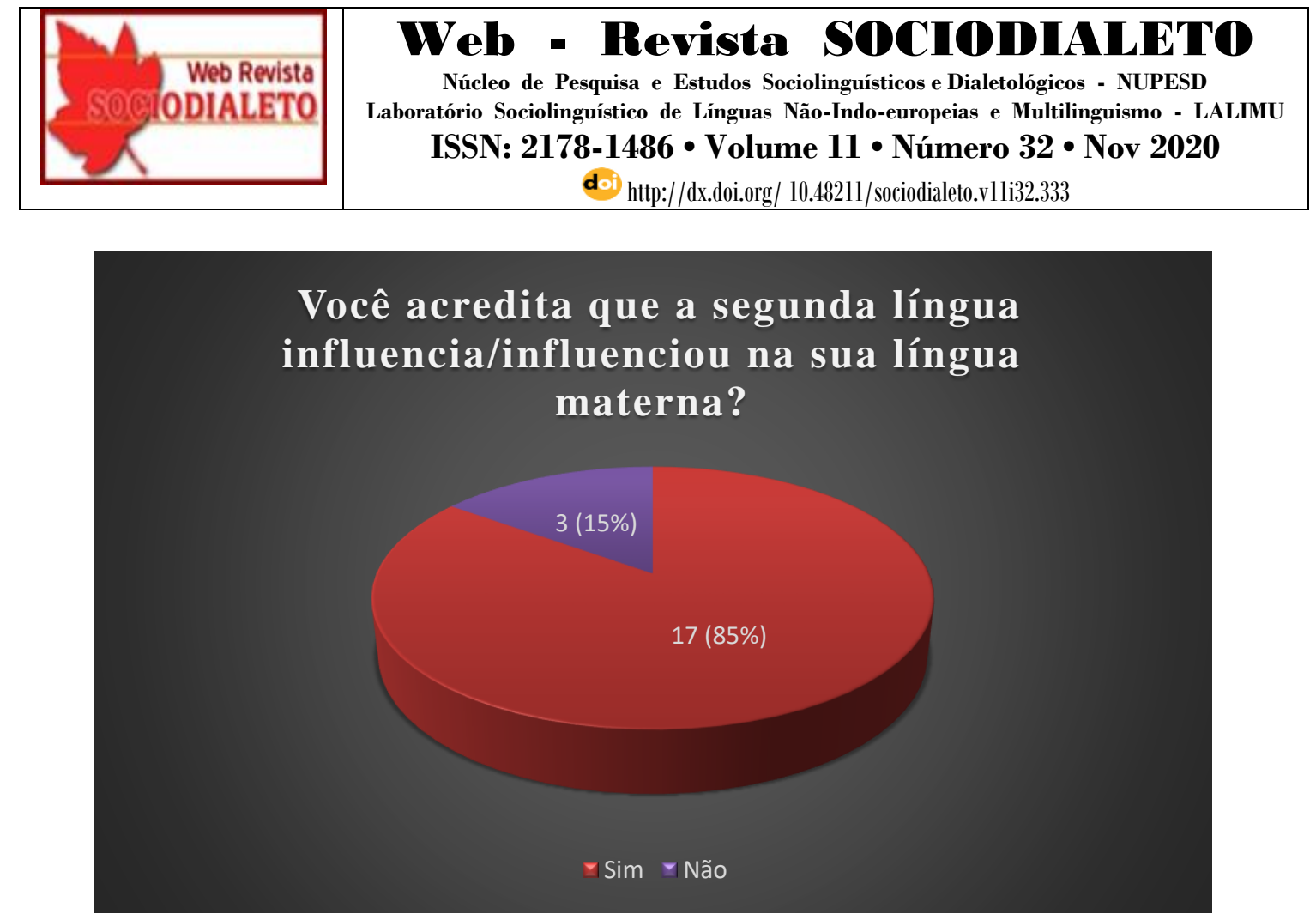

Fonte: Elaborado pelas autoras

Ainda que os entrevistados não soubessem nomear os fenômenos resultantes desse contato e as influências decorrentes dele na língua materna, os catraieiros relatam situações que indicam uma incidência frequente de processos de adaptação e empréstimo de termos de uma língua para outra (português-francês-crioulo); mudança de uma língua pra outra no quotidiano do trabalho, especialmente diante de desconhecidos ou ainda quando não querem ser compreendidos; uso de expressões da segunda língua no cotidiano entre os catraieiros, cuja frequência torna-se de uso comum, entre outras. Questões essas que merecem investigações mais específicas visando maior conhecimento dessa realidade.

\section{Considerações finais}

A pesquisa realizada na região de fronteira entre o município de Oiapoque e Saint - George, região limítrofe entre o Brasil e a Guiana Francesa demarca o contato linguístico do português com o francês, além de diversas outras línguas que circulam no dia a dia dos moradores da região tais como o crioulo guianense e o Khéuol e apresenta o bilinguismo dos catraieiros como um dos principais resultados desse encontro. 


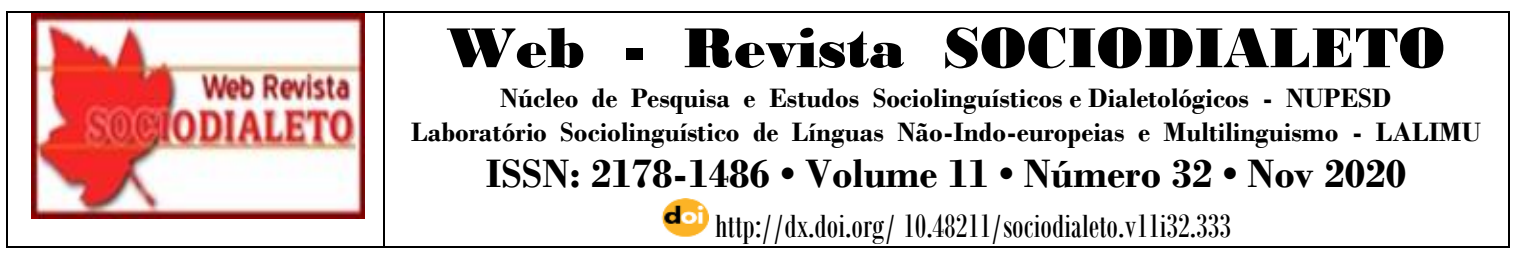

Embora o português seja a língua da maioria da população e também a mais utilizada no ambiente de trabalho, pode-se afirmar que em virtude do peso econômico que representa, a língua francesa evidencia-se como a principal língua da região, sendo esta bastante utilizada pelos moradores dessa zona fronteiriça, especialmente aqueles que desenvolvem alguma atividade comercial.

Constatou-se nessa pesquisa que os trabalhadores catraieiros constituem um grupo majoritariamente bilíngue português/francês ou português/crioulo guianense. O processo de conformação bilíngue desse grupo está baseado na aquisição de uma segunda ou terceira língua no ambiente de trabalho, cuja convivência diária com estrangeiros provenientes da Guiana Francesa tanto possibilita quanto impõe o contato linguístico supramencionado na rotina desses trabalhadores. A escolarização ou o estudo formal de línguas, por sua vez, aparenta não ter tido impacto direto no bilinguismo apresentado pelos catraieiros, sobretudo quando se observa que a ampla maioria cursou apenas o ensino fundamental e poucos tiveram acesso ao ensino de uma língua estrangeira.

Por outro lado, ainda que a aquisição da segunda língua possa ser caracterizada como um processo natural, $50 \%$ dos catraieiros revela ter tido dificuldades em aprender essa nova língua e atribuem o aprendizado ao contato diário e a necessidade que se impunha. De igual maneira, $80 \%$ deles declaram não dominar as competências escritas na segunda língua, ou seja, o bilinguismo desse grupo está diretamente relacionado às funções orais que esses idiomas ocupam no cotidiano.

Finalmente, observou-se que muito embora não tenha surgido uma nova língua do contato português-francês no norte do Brasil, os hábitos linguísticos dos catraieiros, bem como seu repertório linguístico indicam que diversos fenômenos de contato linguístico estão presentes nessa região. Assim, esperamos que esse trabalho contribua para um maior conhecimento dos fenômenos do contato nessa fronteira e possa impulsionar a realização de novas pesquisas.

\section{Referências}




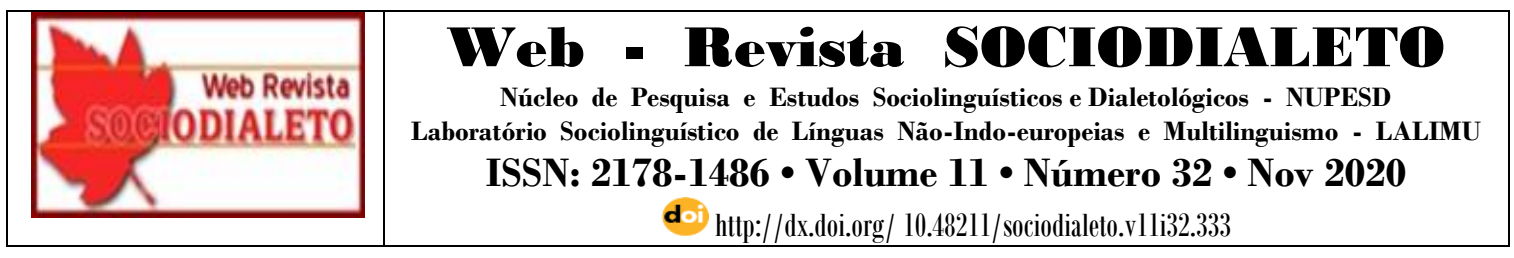

ALTENHOFEN, Cléo V. Política linguística, mitos e concepções linguísticas em áreas bilíngues de imigrantes (alemães) no Brasil. Frankfurt: Revista Internacional de Linguística Iberoamericana (RILI), 2004.

APPEL, René; MUYSKEN, Pieter. Bilinguismo y contacto de lenguas. Barcelona: Editorial Ariel,1996.

CALVET, Jean Louis. Sociolinguística: uma introdução crítica. São Paulo: Parábola, 2002.

CHIAPPINI, Ligia; HAUCK, David. Limites e Lugares. As fronteiras da integração. In: CHIAPPINI, Ligia; HAUCK, Jan-David; TIMM, Liana (Org). Fronteiras da Integração: dimensões culturais do Mercosul. Porto Alegre: Território das Artes, 2011.

DAY, Kelly C. N. A situação Sociolinguística da Fronteira Franco-Brasileira: Oiapoque \& Saint-Georges. Dissertação (Mestrado em Estudos da Linguagem). Pontifícia Universidade Católica do Rio de Janeiro: Rio de Janeiro, 2005.

EDWARDS, John. Foundations of bilingualism. In: BHATIA, Tej K.; RITCHIE, William C. (Ed.). The Handbook of bilingualism. Oxford: Blackwell Publishing Ltd, 2006.

GANSTER, Paul et al. Border and Border Régions in Europe and North América. San Diego: Institute for Regional Studies of the California, 1997.

GASS, Susan.; SELINKER, Larry. Second language acquisition: an introductory course. $3^{\text {a }}$ ed. New York: Routledge: 2008.

GROSJEAN, François. Individual Biligualism. In: The Encyclopedia of Language and Linguistics. Oxford: Pergamon Press, 1994.

HAMERS, Josiane F.; BLANC, Michel H A. Bilingualité et bilinguisme. Bruxelles: Pierre Mardagas Editeur, 1983

HAMERS, Josiane F.; BLANC, Michel H A. Bilinguality and bilingualism, Cambridge: Cambridge University Press, 1989.

LABOV, Willian. The Social Stratification of English in New York City: Center for Applied Linguistics, 1966. In: LABOV, Willian. Sociolinguistic patterns. Philadelphia: University of Pennsylvania, Press, 1972.

LEROY, Maurice. Les grands courants de la linguistique moderne, $2^{\mathrm{a}}$ ed. Bruxelas: Editions de 1'Université de Bruxelles, 1971.

MARCONI, Marina de Andrade; LAKATOS, Eva Maria. Metodologia do Trabalho Científico. São Paulo: Atlas $7^{\mathrm{a}}$ ed. 2013.

MEDINA LÓPEZ, Javier. Lenguas en contacto. Cuadernos de lengua Española. Madrid: Arco Libros, 1997.

MACKEY, William F. Bilinguisme et contact des langues. Klincksieck: Universidade de Michigan, 1976. 


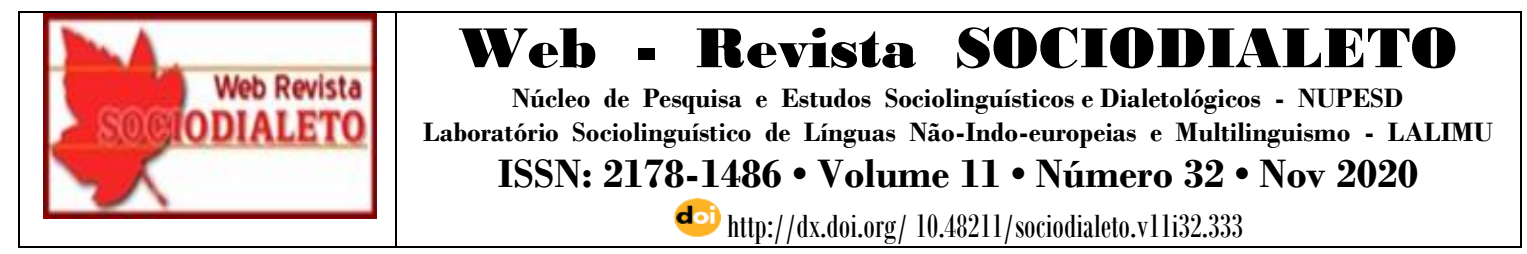

MACKEY, William F. The description of bilingualism. In: FISHMAN, Joshua A. Reading in the sociology of language. $3^{\mathrm{a}}$ ed. The Hague: Mouton, 1972.

MACKEY, William F. Hommage à William F. Mackey. Langues et Linguistiques. Número especial. Quebec: Université Laval, 1992.

PREUSS, Elena Ortiz; ÁLVARES, Margarida Rosa. Bilinguismo e políticas linguísticas no Brasil: da ilusão monolíngue à realidade plurilíngue. Maringá: Acta Scientiarum: Language and Culture, 2014.

RIBEIRO, Celeste Maria da Rocha. O contato linguístico em Oiapoque: algumas considerações sobre a Língua Portuguesa L2 dos falantes franceses. Letras escreve, 2016. Disponível em: https://periodicos.unifap.br/index.php/letras. Acesso em: $07 \mathrm{de}$ Abril de 2020.

ROMAINE, Suzanne. Bilingualism. $2^{\text {a }}$ Ed. Malden: Blackwell, 1997.

STURZA, E. R. Línguas de Fronteira: O Desconhecido Território das Práticas Linguísticas nas Fronteiras Brasileiras. São Paulo: Ciência e Cultura, 2006.

WEINREICH, Uriel. Languages in Contact. Findings and problems. Linguistic Cercle of New York, 1953.

Recebido Para Publicação em 02 de outubro de 2020.

Aprovado Para Publicação em 23 de novembro de 2020. 